University of Wollongong

Research Online

Faculty of Law, Humanities and the Arts Papers (Archive)

Faculty of Arts, Social Sciences \& Humanities

$1-1-2019$

The impending demise of the WTO Appellate Body: from centrepiece to historical relic?

Markus Wagner

University of Wollongong, markusw@uow.edu.au

Follow this and additional works at: https://ro.uow.edu.au/lhapapers

Part of the Arts and Humanities Commons, and the Law Commons

Research Online is the open access institutional repository for the University of Wollongong. For further information contact the UOW Library: research-pubs@uow.edu.au 


\title{
The impending demise of the WTO Appellate Body: from centrepiece to historical
} relic?

\author{
Abstract \\ The current crisis engulfing the multilateral trading system has crystalized in the dispute over the (re- \\ )appointment of the members of the World Trade Organization's Appellate Body. While the legislative arm \\ of the organization has never lived up to its potential, its dispute settlement arm with the Appellate Body \\ at its apex was seen as a lodestar for other international courts and tribunals. The United States has \\ taken issue not only with individual decisions of the Appellate Body (as well as individual Appellate Body \\ members), but with the institution as such. The article recounts the important institutional redesign that \\ has led to the Appellate Body becoming the World Trade Organization's institutional "centerpiece". These \\ very same developments are now destined to lead to the Appellate Body's downfall with potential \\ reverberations for the entire World Trade Organization's dispute settlement process. Moreover, it \\ threatens the institution as a whole, unless some last minute compromise can be found between various \\ competing visions of global economic governance.

\section{Disciplines} \\ Arts and Humanities | Law

\section{Publication Details} \\ M. Wagner, 'The impending demise of the WTO Appellate Body: from centrepiece to historical relic?' in C. \\ Lo, J. Nakagawa \& T. Chen(eds), The Appellate Body of the WTO and its reform (2019) 67-90.
}




\title{
The Impending Demise of the WTO Appellate Body: From Centrepiece to Historical Relic?
}

Markus Wagner, University of Wollongong

\begin{abstract}
The current crisis engulfing the multilateral trading system has crystalized in the dispute over the (re-)appointment of the members of the World Trade Organization's Appellate Body. While the legislative arm of the organization has never lived up to its potential, its dispute settlement arm with the Appellate Body at its apex was seen as a lodestar for other international courts and tribunals. The United States has taken issue not only with individual decisions of the Appellate Body (as well as individual Appellate Body members), but with the institution as such. The article recounts the important institutional redesign that has led to the Appellate Body becoming the World Trade Organization's institutional "centerpiece". These very same developments are now destined to lead to the Appellate Body's downfall with potential reverberations for the entire World Trade Organization's dispute settlement process. Moreover, it threatens the institution as a whole, unless some last minute compromise can be found between various competing visions of global economic governance.
\end{abstract}

Key words: World Trade Organization (WTO), Appellate Body, dispute settlement, international trade, trade, multilateralism

\section{Introduction}

Shortly after the creation of the World Trade Organization (hereinafter WTO) the newly created Appellate Body (hereinafter AB) started to occupy a position of centrality in the governance of international trade law. Through its position at the apex of WTO dispute settlement (unforeseen at the time of its creation), its jurisprudence concerning non-economic values, and its realization of the importance of open and more transparent processes the $\mathrm{AB}$ has contributed greatly towards improving the legitimacy of the WTO in general and the dispute settlement pillar in particular.

The current impasse over the appointments (or lack thereof) for vacant positions on the $\mathrm{AB}$ threatens to relegate its remarkable success story to a historical footnote. The article shows how the AB developed from an afterthought to the "centrepiece" in WTO governance and how the current situation threatens not only the dispute settlement mechanism within the organization, but also wider trade governance. The article recounts the development of the dispute settlement process under the GATT (Part two), highlights how the AB currently occupies a central position within the WTO (Part three), before turning to the criticism leveled against the AB by the United 
States (hereinafter US) as well as other WTO Members' responses (Part four). Part five offers concluding thoughts.

\section{Dispute Settlement in the GATT Years}

The GATT dispute settlement process operated not only without an appellate mechanism, but its dispute settlement mechanism was - at least in comparison to that of the WTO - rudimentary. Articles XXII and XXIII GATT formed the basis for dispute settlement but did not mention the term dispute and it could even be argued from the wording of these provisions that adjudicatory proceedings were not contemplated at the outset. Article XXIII GATT provides that in cases of nullification or impairment (read: at least violation of the GATT ${ }^{1}$ ), "the contracting party may [...] make written representations or proposals to the other contracting party or parties [...]". The only concrete obligation for the addressee laid down in this provision is that "[a]ny contracting party thus approached shall give sympathetic consideration to the representations or proposals made to it."2 Given the scant provision for formal dispute settlement, the GATT's resulting dispute settlement process was remarkable for both its widespread use and track record. ${ }^{3}$ That said, the GATT dispute settlement process suffered serious shortcomings - at least from today's perspective: the establishment of panels and the adoption of reports could be blocked, which in essence meant that at least in the beginning it was hard to call the GATT dispute settlement process an independent legal system. This was best expressed by Robert Hudec who famously characterized the GATT dispute settlement process as "a diplomat's concept of legal order. At least, that is the way it started out." 4 After a promising start, dispute settlement under the GATT feel into disuse during the $1960 \mathrm{~s}^{5}$ and was only resurrected in the 1970s and 1980s. The DISC cases-a series of disputes involving subsidies-laid bare the need for reform beyond what GATT Contracting Parties had agreed to in the Tokyo Round Agreement on Dispute Settlement. ${ }^{6}$ What emerged during that time was a proto-legal system with a legal division within the GATT Secretariat in the early 1980s which led to a higher degree of consistency among the dispute settlement reports and a higher degree of proceduralization of the dispute settlement process. ${ }^{7}$ The subsequent discussions identified the consensus requirement-including the party that lost the case - as a major obstacle, as a negative vote would frustrate the entire purpose of the dispute

${ }^{1}$ Jackson (1998), p. 67.

${ }^{2}$ Article XXIII:1 GATT. A similar provision exists with respect to the consultation stage, see Article XXII:1 GATT.

${ }^{3}$ See Hudec et al. (1993), p. 1-113. The authors call the GATT dispute settlement "accomplishments [...], if not unique, are at least rare in the history of international legal institutions", see $i d$. at p. 97. See also Jackson, supra note 1, at p. 64.

${ }^{4}$ Hudec (1993), p. 7; Davey (1987), p. 61.See generally Reich (1997), pp. 775-849.

${ }^{5}$ Hudec, supra note 4, at pp. 31-34.

${ }^{6}$ For an overview of the disputes, see Jackson (1978). See also Hudec, supra note 4, at pp. 53-57, 130.

${ }^{7}$ Hudec, supra note 4, at pp. 137-138. 
settlement system. Problems connected with expertise, blockage, delays, fragmentation and implementation hampered effective dispute settlement in the GATT years. This found expression in the Punta del Este Ministerial Declaration, which urged that "[i]n order to ensure prompt and effective resolution of disputes to the benefit of all contracting parties, negotiations shall aim to improve and strengthen the rules and the procedures of the dispute settlement process $[\ldots],{ }^{8}$

\section{The WTO Dispute Settlement System's Central Reforms: Reasons for Its Downfall}

It is well-known that the WTO Dispute Settlement Understanding (hereinafter DSU) changed the dispute settlement process considerably. Because a full examination of the manifold changes is beyond the scope of this Chapter, the following section will highlight institutional changes brought about through the DSU as well as some more evolutionary modifications of the dispute settlement process.

\subsection{Institutional Changes}

Among the most important institutional changes are what has come to be known as reverse consensus as well as the very creation of the $\mathrm{AB}$ composed of individuals who hold their positions for once-renewable four-year terms.

\subsubsection{Reverse Consensus}

One of the characteristics that hampered the GATT dispute settlement process was that a government was able to block not only the creation of a dispute settlement panel, but could block the adoption of the report. This gave the losing party a veto, leading to blockage of several dispute settlement processes and reverting the process to political dispute settlement. It was seen by many commentators as the most significant defect in the GATT dispute settlement procedures. ${ }^{9}$

The DSU takes the opposite approach. Not only do WTO members have a right under Article 6.1 DSU to request a panel. A panel or AB decision, while formally requiring adoption by the Dispute Settlement Body (hereinafter DSB) and thus a political organ, ${ }^{10}$ will by default be the final result as the winning party would have

${ }^{8}$ GATT Contracting Parties, see General Agreement on Tariffs and Trade (GATT) Punta del este Declaration, 20 Sep 1986, GATT B.I.S.D.

${ }^{9}$ Jackson, supra note 1 , at p. 68.

${ }^{10}$ Marrakesh Agreement Establishing the World Trade Organization, 15 Apr 1994, 1867 U.N.T.S. 154, Annex 2: Understanding on Rules and Procedures Governing the Settlement of Disputes, Article 2.1 [hereinafter DSU]. 
to object to the adoption of a ruling in its favor. ${ }^{11}$ This has never happened in the history of the WTO, the closest case being Australia - Automotive Leather involving subsidies. ${ }^{12}$ Similarly, the authorization of retaliations follows this reverse or negative consensus rule. ${ }^{13}$

The move from consensus to reverse consensus has important institutional implications: not only did it portend a "quasi-judicialization"14 of dispute settlement or the emergence of the AB as a "World Trade Court". ${ }^{15}$ Potentially even more importantly, it was also a power shift from the political arena of the DSB to the more judicialized processes before panels or the AB. ${ }^{16}$ This power shift is at the center of criticism leveled by the US against the AB.

\subsubsection{Creation of the Appellate Body}

The drafters of the DSU did not foresee how crucial dispute settlement in general and the $\mathrm{AB}$ in particular would become in international trade governance. The $\mathrm{AB}$ functioned - from the very beginning — quite differently from how it was originally envisioned.

The very institution of the $\mathrm{AB}$ as an appeals mechanism created a cultural change in how adjudication worked in the newly created WTO. For one, AB members showed considerably greater independence compared to panel membersnotwithstanding the repeated attempts by the US to undermine $A B$ independence. This is due to $\mathrm{AB}$ members being appointed for once-renewable four year terms, ${ }^{17}$ compared to the ad hoc appointments at the panel stage. ${ }^{18}$ The long-term appointments, combined with institutional mechanisms such as the so-called exchange of views, further contributed to a consistent $A B$ jurisprudence.

$\mathrm{AB}$ decisions are taken by a division of three $\mathrm{AB}$ members. ${ }^{19}$ The exchange of views involves all sitting $\mathrm{AB}$ members and takes place prior to the finalization of a division's report. ${ }^{20}$ Based on the principle of collegiality, the idea underlying the exchange of views is to "draw on the individual and collective expertise of all seven Members". ${ }^{21}$ In the words of a former AB member, these meetings can be "bruising"

${ }^{11}$ See $i d$. at Articles 16.4, 17.14 and 22.6, respectively.

${ }^{12}$ Panel Report, Australia - Subsidies Provided to Producers and Exporters of Automotive Leather - Recourse To Article 21.5 of the DSU by the United States, para 6.48, WT/DS126/RW (21 Jan 2000). The result was heavily criticized by WTO members, including both parties to the dispute and appellate proceedings were only not instituted as both parties had agreed not to do so. See Van den Bossche and Zdouc (2017), p. 208.

${ }^{13}$ DSU, supra note 10, at Articles 6.1, 16.4, 17.14, and 22.6.

${ }_{15}^{14}$ Petersmann (1997), p. 186.

${ }^{15}$ See generally Ehlermann (2002).

${ }^{16}$ See generally on the difference between dispute settlement under the GATT and the WTO, Weiler (2001); Lang (2011), p. 18.

${ }^{17}$ DSU, supra note 10, at Article 17.2.

${ }^{18} \mathrm{Id}$. at Article 8 .

${ }^{19}$ Id. at Article 17.1.

${ }^{20}$ Appellate Body, Working Procedure for Appellate Review, at Article 4(3), WT/AB/WP/6 (16 Aug 2010) [hereinafter Working Procedure].

${ }^{21} I d$., at Article 4(1). See also Steger (2015), p. 457. 
and "certainly expose weak reasoning", with "every argument carefully assessed". 22 Once the exchange of views has run its course, the division finalizes its report. It is not bound to follow the views of the $\mathrm{AB}$ members that are not part of the division deciding a case. The process has however been credited with providing a higher quality to $\mathrm{AB}$ reports, ensuring a higher degree of consistency of the $\mathrm{AB}$ case law on systemic, substantive and procedural issues, and the limited number of separate or dissenting opinions. ${ }^{23}$ The exchange of views thus also contributes to one of the fundamental goals of WTO dispute settlement, i.e. to "providing security and predictability to the multilateral trading system". ${ }^{24}$

Perhaps most importantly, the $\mathrm{AB}$ functioned as a true appeals mechanism visà-vis panel decisions. Initially, there was considerable apprehension about the prospect of a judicial system that would become overly powerful. According to one commentator, the negotiators' purpose in introducing the appellate procedure was that the quasi-automatic adoption of panels reports described above would undergo a light touch check: an appellate mechanism against the occasional "bad" panel report. ${ }^{25}$ This was the tradeoff that some negotiating parties-particularly the European Union (hereinafter EU) and the US - were willing to make in order to remedy "bad" panel reports that both had been exposed to at the time. ${ }^{26}$

It is worth bearing in mind that the $\mathrm{AB}$ was not envisioned as a standing institution at the time, but was to be used on an exceptional basis. This is evidenced by the fact that the members of the $\mathrm{AB}$ were not considered to have to work full-time, but rather could be remunerated on a retainer basis. ${ }^{27}$ But it quickly became clear that the $\mathrm{AB}$ took its role as a true appellate mechanism seriously. While mindful that its findings did not formally possess the power of stare decisis, the $\mathrm{AB}$ increasingly made it clear that prior decisions "provid[e] interpretative guidance for future panels" 28 . Subsequent decisions reinforced this position with the AB making its most commanding statement in this regard when it suggested that a panel decision deviating without reason from $\mathrm{AB}$ jurisprudence constituted a "[failure] to discharge its duties under Article 11 DSU."29

In addition to the institutional reforms just outlined - and partially because of these changes - the $\mathrm{AB}$ jurisprudence with respect to the relationship between the classic economic pursuits of the GATT era, namely trade liberalization, with negative externalities such as threats to human health or the environment, are additional hallmarks of the post-1995 era. This development was evident in the elevation of Article XX GATT as a counterpoint to the non-discrimination clauses of e.g. Articles

${ }^{22}$ Unterhalter (2015), p. 471.

${ }^{23}$ Ehlermann (2005), pp. 477-478; Steger (2004), p. 44.

${ }^{24}$ DSU, supra note 10, at Article 3.2.

${ }^{25}$ Van den Bossche (2005), p. 64. See also Jackson (1997), p. 127.

${ }^{26}$ Van den Bossche (2006), p. 7.

27 Dispute Settlement Body, Establishment of the Appellate Body, Recommendations by the Preparatory Committee for the WTO approved by the Dispute Settlement Body on 10 February 1995 , para 11-12, WT/DSB/1 (19 June 1995).

${ }^{28}$ Appellate Body Report, United States - Import of Certain Shrimp and Shrimp Products, para 107, WT/DS58/AB/RW (22 Oct 2001).

${ }^{29}$ Appellate Body Report, United States - Final Anti-Dumping Measure on Stainess Steel from Mexico, para 162, WT/DS344/AB/R (30 Apr 2008). 
I and III GATT, ${ }^{30}$ but also upon closer analysis of the quite different jurisprudence of the panels and AB in most SPS cases. ${ }^{31}$

\subsubsection{Summary}

Both reverse consensus and the creation of the $\mathrm{AB}$ are institutional mechanisms that had a profound effect on the WTO dispute settlement process. While this may not have been the "reflection of a grand design to create a strong, authoritative court that would be at the epicentre of the new WTO dispute settlement system", 32 it certainly has occupied that position from an early stage. Aware of the potential for a power shift from governmental decision-making that was at the heart of the GATT to one that balances power among different branches of the WTO's constitutional system, AB members, from the very beginning, had an eye on balancing internal and external legitimacy. ${ }^{33}$ This included grounding its jurisprudence-which was oftentimes quite far-reaching and sophisticated - as "textual" and thus resulting from the "ordinary meaning of words", even though in practice the jurisprudence very much took account of the context in which its decisions were embedded. From its earliest decisions - in terms of style, content and self-understanding - the AB behaved like a high court. ${ }^{34}$ Thus its critique of the panel's reasoning in the very first case that reached the $\mathrm{AB}$ - the Gasoline case ${ }^{35}$ - was a harbinger of things to come. Over time the AB created - through a sophisticated jurisprudence-a heightened level of authority within the WTO, albeit one that was going to have to be continuously maintained. ${ }^{36}$

\subsection{Systemic importance of the AB in the WTO system: Contractarian v. Constitutional Views}

As pointed out above, the systemic importance of the AB within the WTO dispute settlement system cannot be overstated. But it is precisely this elevation of the apex institution of WTO dispute settlement compared to the GATT dispute settlement institutions that has caused considerable debate between almost exclusively the US on one side and the overwhelming number of remaining WTO

${ }^{30}$ Cho and Kurtz (2018), p. 187.

${ }^{31}$ See generally Wagner (2011).

${ }^{32}$ Peter Van den Bossche, From Afterthought to Centrepiece: The WTO Appellate Body and its Rise to Prominence in the World Trading System 67 (Faculty of L., U. of Maastricht Working Paper, 2005). See also 67-79 for the reasons of the AB's increased prominence.

${ }^{33}$ Weiler, supra note 16 , at p. 200 et seq.

${ }^{34}$ See generally Ehlermann (2002).

${ }^{35}$ Appellate Body Report, United States - Standards for Reformulated and Conventional Gasoline, WT/DS2/AB/R (29 Apr 1996).

${ }^{36}$ See generally Unterhalter, supra note 22 See also Graham (2014), p. 322; Shaffer et al. (2016), p. 257. 
members. The current debate about the future of the AB goes - in the words of a former $\mathrm{AB}$ member - to "the core and the nature of what the $\mathrm{AB}$ is or should not be". ${ }^{37}$

The former position holds that the WTO Agreement is best viewed as a contractual obligation, with the consequence that the language in any of the organization's agreements should be interpreted narrowly and interpreters should be hewing closely to the negotiator's intentions at the founding of the WTO. ${ }^{38}$ Most other WTO Members view the WTO Agreement as part of a trade constitution with the dispute settlement organs performing an independent function from the membership, empowered to resolve textual ambiguities. ${ }^{39}$ This debate is not as arcane as it may seem at first sight: ${ }^{40}$ the former regards international agreements as perpetually negotiable instruments, while the latter considers the system working towards shared, collective goals of a global community. It is also not a criticism that is new to the WTO, but had already been leveled at GATT dispute panels in the early years of GATT dispute settlement. ${ }^{41}$

If WTO law-as opposed to the early stages of the GATT era-was ever properly characterized as a contract, ${ }^{42}$ its founding treaty and the jurisprudence that was built on that foundation has moved well beyond that stage, and as far as can be observed, without principled opposition. Several factors are important in this context: the combination of institutional design factors laid out above; the imposition of constraints against unilateral action; ${ }^{43}$ a jurisprudence that takes the justifications contained in e.g. Article XX GATT seriously; and WTO Members' acceptance of such jurisprudence-notwithstanding disagreement in particular cases. ${ }^{44}$ These factors are an indication that the WTO is qualitatively different from the GATT not only institutionally, but also substantively and procedurally. ${ }^{45}$ This is particularly true for an institution which is dynamic and adapting to changing circumstances - be that

\footnotetext{
${ }^{37}$ Ramírez-Hernández R (2018) Farewell speech of Appellate Body Member Ricardo RamírezHernández. https://www.wto.org/english/tratop_e/dispu_e/ricardoramirezfarwellspeech_e.htm. Accessed 3 Mar 2019.

${ }^{38}$ Lighthizer R (2017) U.S. Trade Policy Priorities: Robert Lighthizer, United States Trade Representative. https://www.csis.org/analysis/us-trade-policy-priorities-robert-lighthizer-united-sta tes-trade-representative. Accessed 31 Jan 2019 [hereinafter Robert Lighthizer].

${ }^{39}$ Steinberg (2004), p. 271.

${ }^{40}$ Cohen H (2018) International Order between Governance and Contract, 1. http://bit.ly/GOCohen. Accessed 21 Feb 2019.

${ }^{41}$ Jackson, supra note 1, at p. 67. But see Steinberg, supra note 39, at pp. 256-257.

${ }^{42}$ One could read the AB's finding in Japan-Alcoholic Beverages II, stating that "[t]he WTO Agreement is a treaty - the international equivalent of a contract", in such a light. Appellate Body Report, Japan-Taxes on Alcoholic Beverages, p. 15, WT/DS8/AB/R, WT/DS10/AB/R, WT/DS11/AB/R (4 Oct 1996).

${ }^{43}$ Steinberg, supra note 39 , at p. 250 .

${ }^{44}$ Creamer and Godzimirska (2016), p. 320; Howse (2016), pp. 11-12.

${ }^{45}$ See generally Bogdandy and Wagner (2006). Article III WTO Agreement is a positive reflection of the division of functions within-and thus the constitutional design of-the WTO. It outlines thealbeit rather limited-executive (Article III:1 and III:4), as well as the legislative and adjudicative functions (Article III:2 and III:3, respectively). Article III:5, together with Article V, concerns the external relations of the WTO.
} 
actual (such as accession of new members) or jurisprudential developments (as has been the case with Article XX GATT). ${ }^{46}$

\subsection{Failure of the WTO's Legislative Arm}

The elevated position of the dispute settlement organs within the WTO are at least partially due to an almost complete lack of legislative action. ${ }^{47}$ This failure in the separation of powers within the WTO has arguably greatly contributed to the current impasse. The "crown jewel" of the WTO, its dispute settlement process could - and can - only shine as brightly because the other pillars within the WTO have not been fully functional.

Since 1995 there has been little progress in updating the corpus of WTO rules. The Doha Round of Negotiations is formally still ongoing and according to the WTO, "its aim is to achieve major reform of the international trading system through the introduction of lower trade barriers and revised trade rules". ${ }^{48}$ However, a closer look at the legislative achievements in this period is sobering.

\subsubsection{Doha Ministerial Declaration on TRIPS and Public Health}

One of the major achievements is the Doha Ministerial Declaration on The Agreement on Trade-Related Aspects of Intellectual Property Rights (hereinafter TRIPS) and Public Health. ${ }^{49}$ The Declaration "recognizes the "gravity of the public health problems afflicting many developing and least-developed countries, especially those resulting from HIV/AIDS, tuberculosis, malaria and other epidemics", and WTO Members "agree that the TRIPS Agreement does not and should not prevent members from taking measures to protect public health". ${ }^{50}$ On that basis, WTO Members have "the right to grant compulsory licences and the freedom to determine the grounds upon which such licences are granted". ${ }^{51}$ The result of the Declaration was an increase in the use of compulsory licenses for some time after its adoption,

${ }^{46}$ Van Damme (2009), p. 313.

${ }^{47}$ See in this sense remarks by the WTO AB Chair Ujal Singh in 2018 on the occasion of the release of the 2017 AB Report. World Trade Organization (2018) "Unprecedented challenges" confront Appellate Body, chair warns. https://www.wto.org/english/news_e/news18_e/ab_22jun18_e.htm. Accessed 5 Mar 2019.

${ }^{48}$ World Trade Organization (2018) The Doha Round. https://www.wto.org/english/tratop e/dda e/dda_e.htm. Accessed 25 Jan 2019. The latter element is geared towards improving the relative position of developing countries within the WTO and international trade in general.

${ }^{49}$ DOHA WTO Ministerial 2001, Declaration on the TRIPS Agreement and Public Health, 20 November 2001, WT/MIN(01)/DEC/2 (20 Nov 2001).

${ }^{50} I d$. at para 1.

${ }^{51} \mathrm{Id}$. at para $5 \mathrm{~b}$. 
but there now appears to be a low probability of continued such activity. ${ }^{52}$ That said, the Declaration - with the exception of provisions pertaining to developing countries without production capacity ${ }^{53}$ - clarifies rather than changes the existing provisions of the TRIPS Agreement. It does however, set an interpretive baseline for WTO Members to find the proper balance between IP rights holders on the one hand and governments facing situations of epidemics on the other. ${ }^{54}$ This is evident when WTO Members "affirm that the Agreement can and should be interpreted and implemented in a manner supportive of WTO members' right to protect public health and, in particular, to promote access to medicines for all." $" 55$

\subsubsection{Trade Facilitation Agreement}

The most significant new agreement since the WTO's inception in 1995 is the Trade Facilitation Agreement (hereinafter TFA), which was concluded in 2013 and entered into force in February 2017. ${ }^{56}$ The TFA aims to facilitate the cross-border movement of goods (this includes expediting the movement, release and clearance of goods across borders as well as goods in transit), to cooperate more effectively between domestic authorities concerning customs compliance matters, and to provide for technical assistance and capacity building. ${ }^{57}$ This was predicted to reduce the time for border clearance for both imports and exports, thus decreasing the costs by 14.3 per cent ${ }^{58}$ - with the largest gains being made by developing countries. ${ }^{59}$ The TFA replicates developments at the regional level where trade facilitation has played a more prominent role since the 1980s. ${ }^{60}$

When the TFA came into force, the WTO Director-General welcomed this development almost effusively, calling it "the greatest trade reform for a generation". ${ }^{61}$ While the TFA is a sign that the legislative mechanism of the WTO has not withered completely, it is far less ambitious than what appeared possible. If

${ }^{52}$ Beall and Kuhn (2012) Trends in Compulsory Licensing of Pharmaceuticals Since the Doha Declaration: A Database Analysis. https://journals.plos.org/plosmedicine/article?id=10.1371/journ al.pmed.1001154. Accessed 25 Mar 2019.

${ }^{53}$ WTO Declaration on the TRIPS Agreement and Public Health, supra note 49, at para 6.

${ }^{54}$ Gathii (2002), p. 316.

55 WTO Declaration on the TRIPS Agreement and Public Health, supra note 49, at para 4.

${ }^{56}$ World Trade Organization (2017) WTO's Trade Facilitation Agreement enters into force. http s://www.wto.org/english/news_e/news17_e/fac_31jan17_e.htm. Accessed 8 Aug 2017.

${ }^{57}$ See Trade Facilitation Agreement, Nov. 28, 2014, Articles 1 and 5, 7, 8-12, and 13-22, respectively.

${ }^{58}$ World Trade Organization (2017) Annual Report 2017, 72. https://www.wto.org/english/res_e/b ooksp e/anrep e/anrep17 e.pdf. Accessed 8 Aug 2017. See also Arvis et al. (2013), p. 472

${ }^{59}$ World Trade Organization (2015) World Trade Report 2015, 83. https://www.wto.org/english/re s_e/booksp_e/world_trade_report15_e.pdf. Accessed 26 Mar 2019.

${ }^{60}$ See generally Neufeld $\bar{N}$ (2014) Trade Facilitation Provisions in Regional Trade Agreements: Traits and Trends, 5. https://www.wto.org/english/res_e/reser_e/ersd201401_e.pdf. Accessed 30 Jan 2019.

${ }^{61}$ World Trade Organization (2017) From Vision to Reality: Event Celebrates Success of the Trade Facilitation Agreement. https://www.wto.org/english/news_e/news17_e/fac_02jun17_e.htm. Accessed 8 Aug 2017. 
an agreement such as the TFA is considered "ground-breaking", ${ }^{62}$ it is clear that the ambition of the WTO has been scaled back considerably.

\subsubsection{Environmental Goods Agreement}

The Environmental Goods Agreement (hereinafter EGA) is an initiative that was launched in 2014, the underlying idea being the reduction of tariffs for goods that have environmental benefits on a plurilateral basis. ${ }^{63}$ These include solar panels, wind turbines and other energy-efficient products, but also technologies that address issues such as air pollution, waste and water management technologies. ${ }^{64}$ Building on an existing list of 54 environmental goods that was developed under the aegis of the Asia-Pacific Economic Cooperation (hereinafter APEC), ${ }^{65}$ it was to further the goals of the Paris Agreement on climate change as well as the United Nations Sustainable Development Goals by reducing the costs for these products. ${ }^{66} 18$ participants (representing a total of 46 WTO Members through the participation of the EU) were engaging in the negotiations which accounted for the majority of global trade in environmental goods. ${ }^{67}$ While the benefits of the EGA were to accrue to the entire WTO membership, the EGA's future is unclear at this point as talks stalled in late 2016 over which goods should be covered by the agreement as well as phasing out periods. ${ }^{68}$ But even the agreed upon list of goods (comprising of roughly 300 products) was modest: first, tariffs on most of these goods were low to begin with;

${ }^{62} I d$.

${ }^{63}$ This idea was already included in the 2001 Doha Ministerial Declaration, which called for the "the reduction or, as appropriate, elimination of tariff and non-tariff barriers to environmental goods and services". See Ministerial Conference, Ministerial Declaration, at para 31, WT/MIN(01)/DEC/1 (20 Nov 2001).

${ }^{64}$ Australian Government, Department of Foreign Affairs and Trade (2019) Environmental Goods Agreement. https://dfat.gov.au/trade/organisations/wto/negotiations/ega/Pages/environmentalgoods-agreement.aspx. Accessed 30 Jan 2019. For a more expansive definition of environmental goods, see OECD and Statistical Office of the European Communities (1999), p. 9. The OCED posits: "The environmental goods and services industry consists of activities which produce goods and services to measure, prevent, limit, minimise or correct environmental damage to water, air and soil, as well as problems related to waste, noise and eco-systems. This includes cleaner technologies, products and services that reduce environmental risk and minimise pollution and resource use."

${ }^{65}$ Asia-Pacific Economic Cooperation (2012) ANNEX C - APEC List of Environmental Goods. https://www.apec.org/Meeting-Papers/Leaders-Declarations/2012/2012_aelm/2012_aelm_annex C.aspx. Accessed 30 Jan 2019.

${ }^{66}$ Araya M (2016) The Relevance of the Environmental Goods Agreement in Advancing the Paris Agreement Goals and SDGs: A Focus on Clean Energy and Costa Rica's Experience, 8-10. https://www.ictsd.org/sites/default/files/research/the relevance of the environmental goods_agre ement_in_advancing_the_paris_agreement_goals_and_the_sdgs_0.pdf. Accessed 30 Jan 2019.

67 World Trade Organization (2014) Environmental Goods Agreement (EGA). https://www.wto.org/english/tratop_e/envir_e/ega_e.htm. Accessed 26 Mar 2019.

${ }^{68}$ Reuters (2016) WTO environmental trade talks fail. https://www.reuters.com/article/tradeenvironment-idINL5N1DZ0IJ. Accessed 30 Jan 2019; International Centre for Trade and Sustainable Development (2016) Ministerial Talks to Clinch Environmental Goods Agreement Hit Stumbling Block. https://www.ictsd.org/bridges-news/bridges/news/ministerial-talks-to-clinchenvironmental-goods-agreement-hit-stumbling. Accessed 26 Mar 2019. 
second the EGA negotiations did not tackle non-tariff barriers, subsidies, antidumping policies, or intellectual property protections; finally, the environmental benefits were calculated as modest. ${ }^{69}$ There is little doubt that lower tariff on environmental goods would be beneficial in order to allow for the easier spread of e.g. climate change averting technologies. It does not appear however that the major countries involved in this effort will be able to agree on a way forward in the near future. $^{70}$

\subsubsection{Other Legislative Efforts}

Further efforts are currently underway, including an initiative on e-commerce ${ }^{71}$ (following the broad and rather aspirational Chapter 14 CPTPP) and there appears to be space for more ambitious efforts to expand services negotiations. ${ }^{72}$ Progress in both areas would be especially important given the increasing importance of services in the global value chains and the relative decline of trade in goods-producing value chains. $^{73}$

\subsection{Summary}

Taken together, these efforts — while laudable — are and this is putting it mildly, modest in comparison to the work that was carried out in the dispute settlement arm of the WTO. The US has suggested that language in some of the agreements within the WTO embodies "constructive ambiguity", i.e. situations "where the negotiators leave unresolved particular issues by agreeing on language that does not resolve the issue and is capable of more than one interpretation". ${ }^{74}$ Apart from the difficulty in distinguishing where such "constructive ambiguity" exists (and where it does not), Article 3.2 DSU makes it clear that the "dispute settlement system of the WTO is a central element in providing security and predictability to the multilateral trading

${ }^{69}$ Cosbey A (2014) The Green Goods Agreement: Neither Green nor Good?, 1. https://www.iisd.org/sites/default/files/publications/commentary_green_goods.pdf. Accessed 30 Jan 2019; Wooders P (2009) Greenhouse Gas Emission Impacts of Liberalizing Trade in Environmental Goods, 19. https://www.iisd.org/pdf/2009/bali_2_copenhagen_egs.pdf. Accessed 30 Jan 2019.

${ }^{70}$ Sell M (2017) Climate and Trade Policy in a New Era: Options Ahead. https://www.icts d.org/opinion/climate-and-trade-policy-in-a-new-era-options-ahead. Accessed 30 Jan 2019.

${ }^{71}$ Kihara L (2019) Nearly Half WTO Members Agree to Talks on New E-commerce Rules. htt ps://www.reuters.com/article/davos-meeting-ecommerce/davos-nearly-half-wto-members-agree-to -talks-on-new-e-commerce-rules-idUSL1N1ZP08O. Accessed 14 Feb 2019.

${ }^{72}$ World Trade Organization (2019) Services Negotiations. https://www.wto.org/english/tratop_e/s erv_e/s_negs_e.htm. Accessed 14 Feb 2019.

${ }^{73}$ Lund S et al. (2019) Globalization In Transition: The Future of Trade and Value Chains. https://www.mckinsey.com/featured-insights/innovation-and-growth/globalization-in-transition-th e-future-of-trade-and-value-chains. Accessed $14 \mathrm{Feb} 2019$.

${ }^{74}$ Dispute Settlement Body, Negotiations on Improvements and Clarifications of the Dispute Settlement Understanding, TN/DS/W/82/Add.1 (25 Oct 2005). 
system". Panels and the AB would fall short of their duty to provide such security and predictability if they were to engage in selectively picking and choosing when an instance of "constructive ambiguity" actually exists (and where it does not). Rather than blaming the dispute settlement organs for engaging what the DSU mandates them to do, it is incumbent on WTO Members to engage in meaningful discussions of legislative reform.

It goes without saying that reaching political consensus was a difficult task once the WTO was created in 1995. That said, the relatively meagre results of the legislative arm and the extensive jurisprudence - partially because WTO Members made considerable use of the WTO dispute settlement process - are evidence of the imbalance between these two pillars of the WTO. It is also worth bearing in mind that the judicial view and that of negotiators can sometimes be at odds: what $\mathrm{AB}$ members may rightly perceive as a clarification (as opposed to adding to or diminishing rights and obligations of WTO Members ${ }^{75}$ ) has sometimes been understood as interpreting treaty language different from what was originally intended. ${ }^{76}$

\section{US Criticism over the $A B$}

The US has raised specific points of criticism vis-à-vis the WTO AB in late 2018. However, the US has had concerns about the role of the adjudicatory bodies well before the Trump administration came into power in January of $2017 .{ }^{77}$ This section will analyze the more general criticism of the WTO before turning to the specific concerns the US has regarding the AB. Some of these issues are genuine concerns that are best dealt with through a reform of the WTO. Other concerns appear less valid and are likely best understood as distractions.

\subsection{Criticism Against the WTO More Generally}

Beyond dispute settlement-specific issues, the US has made more general remarks critical of the multilateral trade governance currently in place within the WTO. Its criticism of the $\mathrm{AB}$ are best seen in light of these wider-reaching institutional as well as geostrategic concerns.

${ }^{75}$ DSU, supra note 10, at Article 3.2.

${ }^{76}$ See in this sense Robert Lighthizer, supra note 38.

${ }^{77}$ See only Executive Branch Strategy Regarding WTO Dispute Settlement Panels and the Appellate Body: Report to Congress Transmitted by the Secretary of Commerce 7 (30 Dec 2002), cited in Stewart T.P (2017) Disputed Court: A Look at the Challenges to (and from) the WTO Dispute Settlement System, 7-8. http://www.stewartlaw.com/Content/Documents/WTO\%20 Dispute\%20Settlement\%20System\%20-\%20Paper\%20for\%2012-20-17\%20GBD.pdf. Accessed 22 Feb 2019 
These include the aforementioned imbalance between the legislative and judicial arm by stating that "WTO is losing its essential focus on negotiation and becoming a litigation-centered organization". ${ }^{78}$ In as much this criticism is valid, it can also be seen as an attempt to return to the power-based system that existed in the GATT years and that was at least partially overcome with the creation of the WTO in $1995 .{ }^{79} \mathrm{~A}$ second concern is the unclear definition of the term development within the WTO. ${ }^{80}$ This is a long-standing issue within the WTO, as WTO Members self-declare whether they are developing countries. It is not only that drawing lines between these two categories is difficult, but the current system has ossified the divisions that existed at the founding of the WTO. A third criticism is the lack of notifications and transparency, which - in the eyes of the US - makes it impossible to negotiate new trade rules as the existing ones are not being followed. ${ }^{81}$ This is presumably an issue geared at WTO Members who fail to notify and provide transparency over their SPS, TBT and trade remedies obligations. ${ }^{82}$ Finally, the US urges reforms of the substantive rules pertaining to "chronic overcapacity and the influence of stateowned enterprises" as well as "addressing real-world problems such as SPS barriers". ${ }^{83}$ The latter is an agricultural sector interest-driven appeal for less stringent SPS rules, such as those embodied in the Trans-Pacific Partnership Agreement and which have remained unchanged in the re-christened and slightly altered Comprehensive and Progressive Trans-Pacific Partnership Agreement. ${ }^{84}$ The former is a plea against the rise of mercantilism, specifically China's pursuit of an economic model with a stronger emphasis on state involvement and control as well as the pursuit of these policies through subsidies, the creation of national champions, technology transfer, etc. ${ }^{85}$ The United States Trade Representative (hereinafter USTR) does not believe that the existing WTO rules enable other WTO Members to handle China's rise and its accession to the WTO, arguing that more efficient markets are the way forward. ${ }^{86}$ It is this very issue that is at the heart of discussions currently

${ }^{78}$ Lighthizer R (2017) Opening Plenary Statement of USTR Robert Lighthizer at the WTO Ministerial Conference. https://ustr.gov/about-us/policy-offices/press-office/press-releases/2017/de cember/opening-plenary-statement-ustr\#. Accessed 31 Jan 2019.

${ }^{79}$ Jackson (2000), pp. 6-10.

${ }^{80}$ Lighthizer, supra note 78

${ }^{81} \mathrm{Id}$.

${ }^{82}$ See in this regard General Council, Procedures to Enhance Transparency and Strengthen Notification Requirements under WTO Agreements - Communication from Argentina, Costa Rica, the European Union, Japan, and the United States, JOB/GC/204 \& JOB/CTG/14 (1 Nov 2018). In response, WTO Members acknowledged the importance of a transparent multilateral trading system, but also pointed out capacity constraints, in particular for developing countries. See also World Trade Organization (2017) Concerns Grow about Slippage in Subsidy Notifications. https:// www.wto.org/english/news_e/news17_e/scm_25apr17_e.htm. Accessed 22 Feb 2019.

${ }^{83}$ Lighthizer, supra note 78.

${ }^{84}$ See on the approach towards scientific evidence and uncertainty in the TPP/CPTPP, Wagner (2017).

${ }^{85}$ USTR Lighthizer was more specific in his criticism towards China on a different occasion, see Robert Lighthizer, supra note 38.

${ }^{86} \mathrm{Id}$. 
underway between the China and the US in their bilateral trade negotiations and will likely be the defining issue for years to come. ${ }^{87}$

\subsection{Specific Criticism by the US Concerning the Role of the AB and WTO Members' Responses}

While there has been discontent by the US for some time, it raised the most poignant and comprehensive set of criticism in a DSB meeting in late 2018. In that meeting, the US representative pointed out the following areas in which the US thought the AB overstepped its mandate. The US raised the following objections: (1) individuals who are no longer formally members of the $A B$ continue to adjudicate disputes; (2) non-adherence to the 90-day deadline for issuing AB reports; (3) the use of obiter dicta in $\mathrm{AB}$ reports; (4) the AB's misapplication of the standard of review; and (5) taking the view that $\mathrm{AB}$ reports have precedential effect. ${ }^{88} \mathrm{~A}$ further set of objections have been made in other fora, including "transparency issues", "issues with the staff", and the view that the "dispute-settlement process over the years has really diminished what we bargained for or imposed obligations that we do not believe we agreed to". ${ }^{89}$

\subsubsection{Constitutional Backsliding I: Non-(Re)Appointments}

As mentioned before, US criticism towards the WTO overall and the AB in particular is not new. This is best exemplified through what can be seen as the beginning of the constitutional backsliding in the WTO, namely the history of nonappointments or non-reappointments of individuals to the AB. ${ }^{90}$ In all three instances,

\footnotetext{
${ }^{87}$ Mitchell T (2019) China to Rush through New Foreign Investment Law. https://www.f t.com/content/4e60755e-2455-11e9-8ce6-5db4543da632. Accessed 22 Mar 2019:

While the Chinese side has focused on drafting new laws and regulations related to technology transfer and intellectual property protection, US negotiators are demanding an overhaul of Chinese industrial policies, regulatory approvals and concrete steps to combat alleged instances of state-sponsored corporate cyber espionage.

See also Wolf M (2019) The Challenge of One World, Two Systems. https://www.ft.com/content /b20a0d62-23b1-11e9-b329-c7e6ceb5ffdf. Accessed 26 Mar 2019; Mitchell T and Dunkley E (2019) US-China trade talks end with little sign of progress. https://www.ft.com/content/c2783d84 -30ce-11e9-8744-e7016697f225. Accessed 18 Feb 2019; Rappeport A and Landler M (2019) Trump Optimistic on Trade Deal With China, but May Keep Tariffs Anyway. https://www.nytime s.com/2019/01/31/business/trump-china-trade-tariffs.html. Accessed 26 Mar 2019.

${ }^{88}$ United States (2018) Statements by the United States at the Meeting of the WTO General Council. https:/geneva.usmission.gov/wp-content/uploads/sites/290/Dec12.GC_.Stmt_items_.7.a

nd .8.as_delivered.clean_.pdf. Accessed 14 Feb 2019.

${ }^{89}$ Robert Lighthizer, supra note 38.

${ }^{90}$ See generally on the appointment process Elsig and Pollack (2014).
} 
the US prevented the reappointment of an existing $\mathrm{AB}$ member or blocked the appointment process from the very beginning. Like most other decisions within the WTO, appointment and reappointment decisions are by consensus. ${ }^{91}$

The first controversial case was that of US national Jennifer Hillman. Initially appointed in 2007 after serving as a member of the US International Trade Commission, the US refused to support her reappointment in 2011. To be sure, there is no guarantee for reappointment for $\mathrm{AB}$ membership. However, until then no sitting $\mathrm{AB}$ member had not been reappointed and Hillman could not serve another four year term ostensibly because she failed to defend US perspectives..$^{92}$ This is despite the unambiguous language in the DSU and the Working Procedure for Appellate Review that $\mathrm{AB}$ members are "unaffiliated with any government", that members "shall exercise [their] office without accepting or seeking instructions from any international, governmental, or non-governmental organization or any private source", and that "[t]he Members constituting a division shall be selected on the basis of rotation, while taking into account the principles of random selection, unpredictability and opportunity for all Members to serve regardless of their national origin". 93

The second instance of controversy was when the US blocked the appointment of Kenyan national James Gathii. The case is different from the Hillman episode in that Gathii, while teaching at a US law school, is not a US national. It is evident that the DSU and the Working Procedure for Appellate Review provisions are designed to prevent political influence on judicial decision-making. The same cannot be said for the appointment process as such, as that process has become increasingly political. ${ }^{94}$ It is worth noting that Gathii would have been the first and only black African on the $\mathrm{AB}$, but appeared to not be politically palatable for the US, and specifically, the Office of the USTR. ${ }^{95}$

The latest instance of US opposition to reappointment was that of former $\mathrm{AB}$ member Seung Wha Chang from Korea who served on the AB from 2012 until 2016. This situation was different from the two previous instances in that US blocked consensus for a non-US national who had served on the AB. The US opposed Chang because it did "not consider that his service reflects the role assigned to the Appellate Body by WTO Members in the WTO agreements". ${ }^{96}$ The US seemed particularly concerned about Chang's participation in $\mathrm{AB}$ reports, citing "systemic concerns about the disregard for the proper role of the Appellate Body". This includes what the US considered obiter dicta or academic analysis, dealing with issues not raised

\footnotetext{
${ }^{91}$ General Agreement on Tariffs and Trade, 30 Oct 1947, 61 Stat. A-11, 55 U.N.T.S. 194, Article IX.

${ }^{92}$ Hufbauer G.C (2011) WTO Judicial Appointments: Bad Omen for the Trading System. https://pi ie.com/blogs/realtime-economic-issues-watch/wto-judicial-appointments-bad-omen-trading-syste m. Accessed 1 Feb 2019.

${ }^{93}$ DSU, supra note 10, at Article 17.3 and Rule 2(3) and Rule 6(2), respectively of Appellate Body, Working Procedure, supra note 20.

${ }^{94}$ See generally Elsig and Pollack, supra note 90.

95 Pruzin (2014a), p. 150; Pruzin (2014b), p. 793.

${ }^{96}$ United States (2016) Statement by the United States at the Meeting of the WTO Dispute Settlement Body, 1. https://www.wto.org/english/news_e/news16_e/us_statment_dsbmay16_e.pdf. Accessed 14 Feb 2019 [hereinafter Statement].
} 
by parties to the dispute, inventing new legal standards, conducting independent investigations, and not exercising what the US considered proper deference to determinations under domestic law. ${ }^{97}$ Moreover, the US singled out Chang and thus one particular $\mathrm{AB}$ member whose term was about to expire, much to the consternation of other WTO Members as AB reports are confidential and are not attributable to any particular member of the division that has issued a report. ${ }^{98}$

The reaction, more muted in the cases of Hillman (presumably because of her national origin) and Gathii (arguably, among other reasons, because his would have been an initial appointment and because his country of origin is not politically powerful), was uncharacteristically vociferous. Korea considered that any opposition to reappointments should only be for "compelling and legitimate" reasons; the EU said that the U.S. position created a "very serious" situation that may set a negative precedent for the $\mathrm{AB}$ reappointment process and that reappointment of WTO AB members should be "more or less automatic" if a member is able to serve a second term. ${ }^{99}$ Similarly, the Japanese delegation said the U.S. position was "extraordinary, exceptional in nature and [had] no precedent" and furthermore that "[a]ny act by a WTO member of this nature and magnitude must be exercised with extreme caution". ${ }^{100}$ The Brazilian delegation said the justifications outlined by the U.S. "are very far from what would be considered acceptable reasons" and undermined the independence of $\mathrm{AB}$ members, suggesting that WTO Members should consider possibly amending the DSU. ${ }^{101}$

The debate was not confined to WTO members. Not only did former AB members pen a letter, but the situation was considered serious enough that current $\mathrm{AB}$ members took the unprecedented step to enter the debate. All living former $\mathrm{AB}$ members, recognizing the political nature of the (re-)appointment process, remarked that the situation endangered the "impartial independence essential to upholding the rule of law" which had been "central to the success of the WTO dispute settlement system, which has in turn been central to the overall success of the WTO". ${ }^{102}$ The main concern raised by the former $\mathrm{AB}$ members was that one individual had been singled out while all $\mathrm{AB}$ decisions had always been rendered as a division within the $\mathrm{AB}$ and after having gone through the exchange of views. This, in the eyes of the former $\mathrm{AB}$ members, put into jeopardy "all of the accomplishments of the past generation in establishing the credibility of the WTO dispute settlement system" and opened up the "possibility of inappropriate pressures by participants in the WTO trading system". ${ }^{103}$ The letter furthermore points out that "[ $\left.t\right]$ here must be no opening whatsoever to the prospect of political interference in what must remain impartial

${ }^{97} I d$. at pp. $3-5$.

${ }^{98}$ World Trade Organization (2016) WTO members debate appointment/reappointment of Appellate Body members. https://www.wto.org/english/news_e/news16_e/dsb_23may16_e.htm. Accessed 14 Feb 2019.

${ }^{99}$ Id.; Baschuk B (2016) U.S. Blocks Korean Judge From WTO Appellate Body. https://ww w.bna.com/us-blocks-korean-n57982072872/. Accessed 14 Feb 2019.

${ }^{100}$ World Trade Organization, supra note 98.

${ }^{101} \mathrm{Id}$; ; Baschuk B, supra note 99.

102 Appellate Body, Appellate Body Annual Report for 2016, at 103, WT/AB/27 (16 May 2017) [hereinafter Annual Report]. See already Unterhalter, supra note 22, at p. 467.

${ }^{103}$ Annual Report, supra note 102, at p. 104. 
legal judgments in the WTO's rule-based system of adjudication" and that if Members wished to adopt binding interpretations, the WTO Agreement gives that competence to the Ministerial Conference and the General Council under Article XI:2 WTO Agreement. ${ }^{104}$

The - at the time: six - sitting AB members also addressed the DSB in a letter, albeit with a slightly more guarded tone: "The dispute settlement system depends on WTO Members trusting the independence and impartiality of Appellate Body Members. Linking the reappointment of a Member to specific case could affect that trust." ${ }^{105}$ What is remarkable is not the substance - even though some of the points were disputed and criticized by the US representative. ${ }^{106}$ Rather and given the political nature of the process ongoing at the time, it was the fact of the intervention itself. Clearly, the sitting AB members saw the very institution that they represented threatened to the point that they felt compelled to voice their concerns.

\subsubsection{Constitutional Backsliding II: The Reaction - Too Little, Too Late?}

Each of these situations was, in and of itself, serious to warrant more somber consideration of the future of the WTO dispute settlement arm. The reality is that the constitutional backsliding is not a recent phenomenon but has begun quite some time ago. The damage done, other WTO members were either unable or unwilling to challenge the US which - in an ironic twist - had been the driving force behind the creation of an independent and impartial judicial arm at the WTO's creation. ${ }^{107}$ There appeared to be a more unified opposition by WTO Members against the US tactics in the last instance, but this has not prevented the current situation in which the $A B$ consists of only three members (Ujal Singh Bhatia, Thomas Graham and Hong Zhao). ${ }^{108}$

Numerous suggestions have emerged as to how to deal with the current situation. Some are more detail-oriented proposals such as limiting the time that $\mathrm{AB}$ members can serve after their term has expired or for outgoing $\mathrm{AB}$ members to serve until their replacement has been agreed upon; ${ }^{109}$ the Appellate Body could refuse to hear cases; ${ }^{110}$ a separate or modified system for trade remedies (arguably the major substantive concern for the US); ${ }^{11}$ Members could have recourse to majority voting

${ }^{104} I d$.

105 Annual Report, supra note 102, at p. 102.

${ }^{106}$ Statement, supra note 96 , at p. 9.

107 Trebilcock et al. (2012), p. 174.

${ }^{108}$ Correct as of June 2019.

${ }^{109}$ Institute of International Economic Law, Georgetown University Law Center (2018) Transition on the WTO Appellate Body: A Pair of Reforms? https://georgetown.app.box.com/s/jwcvlz2thwtv 3dhgdne0nkfk3vlpv3sf. Accessed 15 Feb 2019.

${ }^{110}$ Charnovitz S (2017) How to Save WTO Dispute Settlement from the Trump Administration. htt ps://worldtradelaw.typepad.com/ielpblog/2017/11/how-to-save-wto-dispute-settlement-from-the-tr ump-administration.html. Accessed 15 Feb 2019.

${ }^{111}$ See e.g. Payosova T et al. (2018) The Dispute Settlement Crisis in the World Trade Organization: Causes and Cures, 8. https://piie.com/system/files/documents/pb18-5.pdf. Accessed 19 Feb 2019. See Robert Lighthizer, supra note 38. 
instead of the default consensus option in WTO decision-making; ${ }^{112}$ disputing Members could agree ex ante to refrain from appealing a panel decision; ${ }^{113}$ arbitration under Article $25 \mathrm{DSU}$ in lieu of appeals to the $\mathrm{AB} ;{ }^{114}$ the introduction of a legislative remand, ie a requirement that panels or the $\mathrm{AB}$ would submit issues of legal uncertainty to WTO committees for further discussion and negotiation; ${ }^{115}$ all the way to outsourcing appellate decision-making to an extra-WTO institution with essentially the same rules and personnel as are currently in place. ${ }^{116}$

Formal reform proposals have been lodged by various groupings within the WTO. The so-called Ottawa Group of 13 like-minded WTO Members, both developing and developed, released a statement pointing out the duty of all WTO Members to "safeguard the WTO dispute settlement system", including "to hold solution-oriented discussions with a view to restoring a fully operational Appellate Body without delay". ${ }^{117}$ This document referenced an earlier proposal by various WTO Members which sets out concrete proposals on the issues raised by the US, including transitional rules pertaining to outgoing $\mathrm{AB}$ members; the length of appellate review; the meaning of municipal law as an issue of fact; the matter of obiter dicta in AB reports; annual meetings between the AB and the DSB "to provide an additional 'channel of communication' where concerns with regard to some Appellate Body approaches, systemic issues or trends in the jurisprudence could be voiced"; 118 as well as the issue of precedent. ${ }^{119}$ Another communication submitted by the EU, China India and Montenegro contained proposals that built on and went further than the previously mentioned document, putting forth a single 6-8 year long term for $\mathrm{AB}$ members in order to "enhance the independence of the $\mathrm{AB}$ and its members"; increase the number of $\mathrm{AB}$ members from 7 to 9 in order to improve efficiency and geographical balance; making $\mathrm{AB}$ membership an exclusive occupation; expanding the resources for the $\mathrm{AB}$ and its Secretariat; and an automatic launch of the selection process to replace outgoing AB members. ${ }^{120}$

\footnotetext{
${ }^{112}$ Kuijper (2017), p. 9. For a counterview, see Hillman J (2018) Three Approaches to Fixing The World Trade Organization's Appellate Body: The Good, the Bad and the Ugly?, 9-14. https://geor getown.app.box.com/s/966hfv0smran4m31biblgfszj42za40b. Accessed 15 Feb 2019.

${ }^{113}$ Salles L.E. (2017) Bilateral Agreements as an Option to Living through the WTO AB Crisis. https://worldtradelaw.typepad.com/ielpblog/2017/11/guest-post-on-bilateral-agreements-as-an-opti on-to-living-through-the-wto-ab-crisis.html. Accessed 19 Feb 2019. Salles cites three previous cases in which the parties had agreed not to appeal: DS126, DS 335 and DS383.

${ }^{114}$ Hillman J, supra note 112, at pp. 8-9.

${ }^{115}$ See in this sense, Lighthizer, supra note 78.

${ }^{116}$ Kuijper, supra note 112, at pp. 10-11.

117 World Trade Organization, Joint Communique of the Ottawa Group on WTO Reform, Communication from Canada, WT/L/1057 (25 Jan 2019).

${ }^{118}$ On this particular issue, see Paine J (2018) The Functions of the WTO's Dispute Settlement Body: A Distinctive Voice Mechanism. https://papers.ssrn.com/sol3/papers.cfm?abstract_id=3208984. Accessed 22 Feb 2019

119 See generally General Council, Communication from the European Union, China, Canada India, Norway, New Zealand, Switzerland, Australia, Republic Of Korea, Iceland, Singapore, Mexico, Costa Rica and Montenegro to the General Council, WT/GC/W/752/Rev.2 (11 Dec 2018).

${ }^{120} \mathrm{General}$ Council, Communication from The European Union, China, India and Montenegro to the General Council, WT/GC/W/753/Rev.1 (11 Dec 2018).
} 
These proposals - in part as direct rejoinders to US criticism—received, at best, a lukewarm response from the US which went as far as stating that "[w] ith respect to the proposal advanced by the EU, China, and India, it is hard to see how it in any way responds to the concerns raised by the US, as some have alleged." ${ }^{21}$ It furthermore responded that "on a close reading, the proposals would not effectively address the concerns that Members have raised" and rather "endorse changing the rules to accommodate and authorize the very approaches that have given rise" to its concerns. $^{122}$

Given these events it seems clear that good faith negotiations on meaningful reform of the WTO dispute settlement system is challenging at best and illusive at worst. ${ }^{123}$ It is hard to reconcile these competing positions or synthesize them into a blueprint for a future dispute settlement process on the multilateral level, short of one side giving up some of their fundamental - though not necessarily genuinedemands.

\section{Conclusion}

The apparent slow demise of the appellate function - and with it most likely the entire adjudicative function of the WTO-will have considerable institutional ramifications. Barring any new developments, the $\mathrm{AB}$ will cease to function no later than December 2019 when the number of $\mathrm{AB}$ members will dip below the requisite three to adjudicate disputes. If this comes to pass, the $\mathrm{AB}$ will have regressed-from the "centrepiece" it was after the WTO's creation-into irrelevance. While some of the criticism raised shouldn't be brushed aside, the AB is caught in a perfect storm of competing visions for international economic governance well beyond its control, and a US administration that appears opposed to multilateral institutions at best and belligerent towards them at worst. The US has long criticized the AB's position in the area of trade remedies, and the ascent of Robert Lighthizer to the position of USTR has only added fuel to the fire of these efforts.

The attempts to dismantle the existing system of dispute settlement are therefore borne out of a sense of frustration at the AB not falling in line with the US' position and desire to return to a power-based system of trade governance. ${ }^{124}$ But in another

${ }^{121}$ United States, supra note 88.

${ }^{122} I d$.

${ }^{123}$ In the context of the-failed, due to US opposition-re-appointment of former AB member Servansing in September 2018-one senior official was reported as saying that "the Americans are not being very lucid about what they want and what exactly it is that they will settle for. They have pointed to their grievances, but not laid out in any meaningful way what exactly are the changes they are looking for". See Freedman J (2018) Insight: Will US 'Light Another Fire' over Servansing's Bid for Second Appellate Body Term? https://borderlex.eu/us-urged-not-to-lightanother-fire-over-servansings-bid-for-second-appellate-body-term/. Accessed 21 Feb 2019.

${ }^{124}$ Robert Lighthizer, supra note 38. For an almost identical view, see Stewart T.P. (2018) The Broken Multilateral Trade Dispute System, 30-31. http://www.stewartlaw.com/Content/Document s/Terence\%20P.\%20Stewart\%20-\%20The\%20Broken\%20Multilateral\%20Trade\%20Dispute\%20 System.pdf. Accessed 19 Feb 2019. 
sense the $\mathrm{AB}$ is collateral damage in a larger battle over the future of international trade governance. The $\mathrm{AB}$ has been thrust into an exposed and vulnerable position partly because of the paralyzed negotiating function of the WTO by the very members that are unable to secure a negotiated settlement for contentious issues. Fixing technical legal issues within the DSU over the proper position of the AB in WTO dispute settlement will likely prove futile in this larger game. ${ }^{125}$ The bigger questions that have remained unresolved are indeed best dealt with at a political level, provided that they are approached in good faith. ${ }^{126}$ Some of these existed prior to China's accession to the WTO in 2001, some have emerged since. At the heart of the current crisis lies the question of competing models: the market-oriented traditional model versus Chinese state capitalism in tandem with the specific distortions it causes. ${ }^{127}$ This central concern is not only relevant for the US, but also many of its (erstwhile) allies in the multilateral trading system.

\section{References}

Australian Government, Department of Foreign Affairs and Trade (2019) Environmental Goods Agreement. https://dfat.gov.au/trade/organisations/wto/negotiations/ega/Pages/environmentalgoods-agreement.aspx. Accessed 30 Jan 2019.

Araya M (2016) The Relevance of the Environmental Goods Agreement in Advancing the Paris Agreement Goals and SDGs: A Focus on Clean Energy and Costa Rica's Experience. https://www.ictsd.org/sites/default/files/research/the_relevance_of_the_environmental_goods_agre ement in advancing the paris agreement goals and the sdgs 0.pdf. Accessed 30 Jan 2019.

Arvis J et al. (2013) Trade Costs in the Developing World: 1995-2010. World Trade Rev. 15:451-474

Asia-Pacific Economic Cooperation (2012) ANNEX C - APEC List of Environmental Goods. https://www.apec.org/Meeting-Papers/Leaders-Declarations/2012/2012_aelm/2012_aelm_annex C.aspx. Accessed 30 Jan 2019.

Baschuk B (2016) U.S. Blocks Korean Judge From WTO Appellate Body. https://www.bna.com/usblocks-korean-n57982072872/. Accessed 14 Feb 2019.

Beall and Kuhn (2012) Trends in Compulsory Licensing of Pharmaceuticals Since the Doha Declaration: A Database Analysis. https://journals.plos.org/plosmedicine/article?id=10.1371/journ al.pmed.1001154. Accessed 25 Mar 2019.

Bogdandy A and Wagner M (2006) Article III WTO Agreement - Functions of the WTO. In: Stoll PT and Schorkopf F (eds) Max Planck Commentaries on World Trade Law: WTO - Institutions and dispute settlement. Martinus Nijhoff Publishers, Leiden

Charnovitz S (2017) How to Save WTO Dispute Settlement from the Trump Administration https://worldtradelaw.typepad.com/ielpblog/2017/11/how-to-save-wto-dispute-settlement-fromthe-trump-administration.html. Accessed 15 Feb 2019

\footnotetext{
${ }^{125}$ McDougall R (2017) The Search for Solutions to Save the WTO Appellate Body, 2. https://ecip e.org/wp-content/uploads/2017/12/Bulletin-03.17.pdf. Accessed 21 Feb 2019.

${ }^{126}$ Lester S (2018) Commentary: Trump's Dangerous Approach to the 'Supreme Court' of Global Trade. https://www.reuters.com/article/us-lester-wto-commentary/commentary-trumps-dangerousapproach-to-the-supreme-court-of-global-trade-idUSKBN1JF1UI. Accessed 5 Mar 2019.

${ }^{127}$ Fabry E and Tate E (2018) Saving the WTO Appellate Body or Returning to the Wild West of Trade?, 15. http://institutdelors.eu/wp-content/uploads/2018/05/SavingtheWTOAppellateBody-Fa bryTate-June2018.pdf. Accessed 22 Feb 2019.
} 
Cho S and Kurtz J (2014) Convergence and Divergence in International Economic Law and Politics. European J Int Law 29(1):169-203

Cohen H (2018) International Order between Governance and Contract. http://bit.ly/GOCohen. Accessed $21 \mathrm{Feb} 2019$

Cosbey A (2014) The Green Goods Agreement: Neither Green nor Good? https://www.iisd.org/sites/default/files/publications/commentary_green_goods.pdf. Accessed 30 Jan 2019

Creamer CD and Godzimirska Z (2016) (De)Legitimation at the WTO Dispute Settlement Mechanism. Vanderbilt J Transnational Law 49:275-321

Davey WJ (1987) Dispute Settlement in GATT. Fordham Int Law J 11:51-109

Ehlermann C (2002) Six Years on the Bench of the "World Trade Court" - Some Personal Experiences as Member of the Appellate Body of the World Trade Organization. J World Trade 36(4):605-639

Ehlermann C (2005) Experiences from the WTO Appellate Body. Tex Int Law J 38(3):469-488

Elsig M and Pollack MA (2014) Agents, Trustees, and International Courts: Nomination and Appointment of Judicial Candidates in the WTO Appellate Body. Eur J Int Relations 20:391-415

Fabry E and Tate E (2018) Saving the WTO Appellate Body or Returning to the Wild West of Trade? http://institutdelors.eu/wp-content/uploads/2018/05/SavingtheWTOAppellateBody-FabryTateJune2018.pdf. Accessed 22 Feb 2019

Freedman J (2018) Insight: Will US "Light Another Fire" over Servansing's Bid for Second Appellate Body Term? https://borderlex.eu/us-urged-not-to-light-another-fire-over-servansings-bid-forsecond-appellate-body-term/. Accessed 21 Feb 2019.

Gathii JT (2002) The Legal Status of the Doha Declaration on TRIPS and Public Health under the Vienna Convention on the Law of Treaties. Harv J Law Techol 15:291-317

Graham TR (2014) Present at the Creation. J Int Business and Law 12(2):317-325

Hillman J (2018) Three Approaches to Fixing The World Trade Organization's Appellate Body: The Good, the Bad and the Ugly? https://georgetown.app.box.com/s/966hfv0smran4m31biblgfszj42za40b. Accessed 15 Feb 2019

Howse R (2016) The World Trade Organization 20 Years On: Global Governance by Judiciary. Eur J Int Law 27(1):9-77

Hudec RE (1993) Enforcing International Trade Law: The Evolution of the Modern GATT Legal System. Butterworth Legal Publishers, Oxford

Hudec RE et al. (1993) A Statistical Profile of GATT Dispute Settlement Cases: 1948-1989. Minn J Glob Trade 2 (1): 1-113

Hufbauer GC (2011) WTO Judicial Appointments: Bad Omen for the Trading System. https:/pi ie.com/blogs/realtime-economic-issues-watch/wto-judicial-appointments-bad-omen-trading-syste m. Accessed 1 Feb 2019

Institute of International Economic Law, Georgetown University Law Center (2018) Transition on the WTO Appellate Body: A Pair of Reforms? https://georgetown.app.box.com/s/jwcvlz2thwtv3dhgdne0nkfk3vlpv3sf. Accessed 15 Feb 2019

International Centre for Trade and Sustainable Development (2016) Ministerial Talks to Clinch Environmental Goods Agreement Hit Stumbling Block. https://www.ictsd.org/bridgesnews/bridges/news/ministerial-talks-to-clinch-environmental-goods-agreement-hit-stumbling

Jackson JH (1978) The Jurisprudence of International Trade: The DISC Case in GATT. American J Int Law 72(4):747-781

Jackson JH (1997) The World Trading System: Law and Policy of International Economic Relations. Massachusetts Institute of Technology Press, Massachusetts

Jackson JH (1998) World Trade Organization: Constitution and Jurisprudence. Royal Institute of International Affairs, London

Jackson JH (2000) The Jurisprudence of GATT and the WTO: Insights on Treaty Law and Economic Relations. Cambridge University Press, Cambridge

Kihara L (2019) Nearly Half WTO Members Agree to Talks on New E-commerce Rules. htt ps://www.reuters.com/article/davos-meeting-ecommerce/davos-nearly-half-wto-members-agreeto-talks-on-new-e-commerce-rules-idUSL1N1ZP08O. Accessed 14 Feb 2019

Kuijper PJ (2018) The US Attack on the WTO Appellate Body. Legal Issues of Econ. Integration 45:111 
Lang A (2011) World Trade Law after Neoliberalism Reimagining the Global Economic Order. Oxford University Press, Oxford

Lester S (2018) Commentary: Trump's Dangerous Approach to the 'Supreme Court' of Global Trade. https://www.reuters.com/article/us-lester-wto-commentary/commentary-trumps-dangerousapproach-to-the-supreme-court-of-global-trade-idUSKBN1JF1UI. Accessed 5 Mar 2019

Lighthizer R (2017) U.S. Trade Policy Priorities: Robert Lighthizer, United States Trade Representative. https://www.csis.org/analysis/us-trade-policy-priorities-robert-lighthizer-united-sta tes-traderepresentative. Accessed 31 Jan 2019

Lighthizer R (2017) Opening Plenary Statement of USTR Robert Lighthizer at the WTO Ministerial Conference. $\quad$ https://ustr.gov/about-us/policy-offices/press-office/pressreleases/2017/december/opening-plenary-statement-ustr\#. Accessed 31 Jan 2019

Lund S et al. (2019) Globalization In Transition: The Future of Trade and Value Chains. https://www.mckinsey.com/featured-insights/innovation-and-growth/globalization-in-transition-th e-future-of-trade-and-value-chains. Accessed $14 \mathrm{Feb} 2019$

McDougall R (2017) The Search for Solutions to Save the WTO Appellate Body. https://ecipe.org/wpcontent/uploads/2017/12/Bulletin-03.17.pdf. Accessed 21 Feb 2019

Mitchell $T$ (2019) China to Rush through New Foreign Investment Law. https://www.f t.com/content/4e60755e-2455-11e9-8ce6-5db4543da632. Accessed 22 Mar 2019

Neufeld N (2014) Trade Facilitation Provisions in Regional Trade Agreements: Traits and Trends. https://www.wto.org/english/res_e/reser_e/ersd201401_e.pdf. Accessed 30 Jan 2019

Paine J (2018) The Functions of the WTO's Dispute Settlement Body: A Distinctive Voice Mechanism. https://papers.ssrn.com/sol3/papers.cfm?abstract_id=3208 984. Accessed 22 Feb 2019

Payosova T et al. (2018) The Dispute Settlement Crisis in the World Trade Organization: Causes and Cures. https://piie.com/system/files/documents/pb18-5.pdf. Accessed 19 Feb 2019

Petersmann E (1997) The GATT/WTO Dispute Settlement System - International Law, International Organizations and Dispute Settlement. Martinus Nijhoff Publishers, Leiden

Pruzin D (2014a) WTO Selection Panel to Recommence Search For Appellate Body Judge Following Deadlock. Int Trade Rep 31:150

Pruzin D (2014b) WTO DSB Chairman Proposes Process For Filling Contested Appellate Vacancy. Int Trade Rep 31:793

Ramírez-Hernández R (2018) Farewell speech of Appellate Body Member Ricardo Ramírez-Hernández. https://www.wto.org/english/tratop_e/dispu_e/ricardoramirezfarwellspeech_e.htm. Accessed 3 Mar 2019

Reich A (1997) From Diplomacy to Law: The Juridicization of International Trade Relations. Northwestern J Int Law \& Business 17:775-849

Reuters (2016) WTO environmental trade talks fail. https://www.reuters.com/article/trade-environmentidINL5N1DZ0IJ. Accessed 30 Jan 2019

Salles L.E. (2017) Bilateral Agreements as an Option to Living through the WTO AB Crisis. https://worldtradelaw.typepad.com/ielpblog/2017/11/guest-post-on-bilateral-agreements-as-anoption-to-living-through-the-wto-ab-crisis.html. Accessed 19 Feb 2019

Sell M (2017) Climate and Trade Policy in a New Era: Options Ahead. https://www.icts d.org/opinion/climate-and-trade-policy-in-a-new-era-options-ahead. Accessed 30 Jan 2019

Shaffer G et al. (2016) The Extensive (But Fragile) Authority of the WTO Appellate Body. Law \& Contemp Probl 79:237-273

Steinberg RH (2004) Judicial Lawmaking at the WTO: Discursive, Constitutional, and Political Constraints. Am J. Int Law 98(2):247-275

Steger DP (2004) Improvements and Reform of the WTO Appellate Body. In: Ortino F and Petersmann E (eds) The WTO Dispute Settlement System, 1995-2003. Kluwer Law International, New York, pp $41-49$

Steger DP (2015) The Founding of the Appellate Body. In: Marceau G (eds) A History of Lawyers in the GATT/WTO: The Development of the Rule of Law in the Multilateral Trading System. Cambridge University Press, Cambridge, pp 447-465

Stewart TP (2017) Disputed Court: A Look at the Challenges to (and from) the WTO Dispute Settlement System.

$\mathrm{http}: / /$ www.stewartlaw.com/Content/Documents/WTO\%20 
Dispute\%20Settlement\%20System\%20-\%20Paper\%20for\%2012-20-17\%20GBD.pdf. Accessed 22 Feb 2019

Stewart TP (2018) The Broken Multilateral Trade Dispute System. http://www.stewartlaw.com/Content/Document s/Terence\%20P.\%20Stewart\%20\%20The\%20Broken\%20Multilateral\%20Trade\%20Dispute\%20 System.pdf. Accessed 19 Feb 2019

Trebilcock M et al. (2013) The Regulation of International Trade. Routledge, London

United States (2016) Statement by the United States at the Meeting of the WTO Dispute Settlement Body. https://www.wto.org/english/news_e/news16_e/us_statment_dsbmay16_e.pdf. Accessed 14 Feb 2019

United States (2018) Statements by the United States at the Meeting of the WTO General Council. https://geneva.usmission.gov/wp-content/uploads/sites/290/Dec12.GC_.Stmt_items_.7.a nd .8.as .delivered.clean .pdf. Accessed 14 Feb 2019

Unterhalter D (2015) The Authority of an Institution: The Appellate Body under Review. In: Marceau G (eds) A History of Lawyers in the GATT/WTO: The Development of the Rule of Law in the Multilateral Trading System. Cambridge University Press, Cambridge, pp 466-475

Van Damme I (2009) Treaty Interpretation by the WTO Appellate Body. Oxford University Press, Oxford

Van den Bossche P (2005) The Making of the World Trade Court: The Origins and Development of the Appellate Body of the World Trade Organization. In: Yerxa R and Wilson B (eds) Key Issues in WTO Dispute Settlement. Cambridge University Press, Cambridge, pp 63-79

Van den Bossche P (2006) From Afterthought to Centrepiece: The WTO Appellate Body and its Rise to Prominence in the World Trading System. In: Sacerdoti G et al. (eds) The WTO at Ten: The Contribution of the Dispute Settlement System. Cambridge University Press, Cambridge, pp 289301

Van den Bossche P and Zdouc W (2017) The Law and Policy of the World Trade Organization: Text, Cases, and Materials. Cambridge University Press, Cambridge

Wagner M (2011) Law Talk v. Science Talk: The Languages of Law and Science in WTO Proceedings. Fordham Int Law J 35(1):151-200

Wagner M (2017) The Future of Sanitary and Phytosanitary Governance: SPS-Plus or SPS-Minus? J World Trade 51(3):445-469

Weiler JHH (2001) The Rule of Lawyers and the Ethos of Diplomats - Reflections on the Internal and External Legitimacy of WTO Dispute Settlement. J World Trade 35(2):191-207

Wolf M (2019) The Challenge of One World, Two Systems. https://www.ft.com/content/b20a0d62-23b111e9-b329-c7e6ceb5ffdf. Accessed 26 Mar 2019

Wooders P (2009) Greenhouse Gas Emission Impacts of Liberalizing Trade in Environmental Goods. https://www.iisd.org/pdf/2009/bali_2 copenhagen egs.pdf. Accessed 30 Jan 2019

World Trade Organization (2014) Environmental Goods Agreement (EGA). https://www.wt o.org/english/tratop_e/envir_e/ega_e.htm. Accessed 26 Mar 2019

World Trade Organization (2015) World Trade Report 2015. https://www.wto.org/english/re s_e/booksp_e/world_trade_report15_e.pdf. Accessed 26 Mar 2019

World Trade Organization (2016) WTO members debate appointment/reappointment of Appellate Body members. https://www.wto.org/english/news_e/news16_e/dsb_23may16_e.htm. Accessed 14 Feb 2019

World Trade Organization (2017) WTO's Trade Facilitation Agreement enters into force. http s://www.wto.org/english/news e/news17 e/fac 31 jan17 e.htm. Accessed 8 Aug 2017

World Trade Organization (2017) From Vision to Reality: Event Celebrates Success of the Trade Facilitation Agreement. https://www.wto.org/english/news_e/news17_e/fac 02jun17 e.htm. Accessed 8 Aug 2017

World Trade Organization (2017) Concerns Grow about Slippage in Subsidy Notifications. https:// www.wto.org/english/news_e/news17_e/scm_25apr17_e.htm. Accessed 22 Feb 2019

World Trade Organization (2018) The Doha ${ }^{-}$Round. ${ }^{-}$https://www.wto.org/english/tratop_e/dda e/dda_e.htm. Accessed 25 Jan 2019

World Trade Organization (2018) "Unprecedented challenges" confront Appellate Body, chair warns. https://www.wto.org/english/news_e/news18_e/ab_22jun18_e.htm. Accessed 5 Mar 2019

World Trade Organization (2019) Services Negotiations. https://www.wto.org/english/tratop e/s erv_e/s_negs_e.htm. Accessed 14 Feb 2019 